\title{
USE OF THEORETICAL MATHEMATICAL RELATIONS FOR CALCULATING THE APPLICATION AND MASS FLOW RATE OF A REAR DELIVERY VERTICAL-AXIS MANURE SPREADER
}

\author{
Ştefan Vasilica ${ }^{1}$, David Ladislau ${ }^{2}$, Popa Lucreția ${ }^{1}$, Zaica Alexandru ${ }^{1}$ \\ ${ }^{1}$ National Institute of Research - Development for Machines and Installations Designed \\ to Agriculture and Food Industry, Romania; ${ }^{2}$ P.U. Bucharest, Romania \\ valle_vali@yahoo.com, david.ladislau@yahoo.com, lucretia_popa@yahoo.com, \\ zaica_alexandru@yahoo.com
}

\begin{abstract}
In the context of protecting and maintaining the health of the population, development and implementation of technically innovative, high performance solutions for manure spreading machinery, is an important research direction worldwide and in Romania as well. Pursuing concerns of the manufacturers and researchers in the field, there is an enhanced interest in the production of equipment for fertilization, starting with classic trailers with rear delivery horizontal-axis beaters, followed by the rear delivery vertical-axis beaters, side delivery flails, and finally reaching the advanced equipment comprising a rear delivery centrifugal table with automatic flow control. Based on the theoretical relations of mass flow rate, and considering a coefficient of correction due to material compression in the hopper, one can determine the application and discharge rates that can be achieved with a manure spreader equipped with vertical rotors in different working conditions. The difference between the conveyor speed and the speed of conveyed material as well as the friction between material and the hopper walls is also considered.
\end{abstract}

Keywords: application rate, discharge rate, floor conveyor, hopper, manure spreader, mass flow rate.

\section{Introduction}

Organic fertilizers used in agriculture provide a part of the total of nutritional elements for plant feeding, and contribute to improving the physical, chemical and biological characteristics of the soil and raise the humus content. They can be administered directly by incorporating in well-established soils below the ploughing line, and at the recommended dose for each crop. They can be used in either the fresh or the semi-fermented form. Furthermore, they are used efficiently by application to the precursory crop.

Each type of soil provides a certain level of production, and a further increase in production can be ensured by compliance with all technological links as well as providing proper plant nutrients. The provision of necessary nutrients is made by combining natural fertilizers (organic) with mineral fertilizers (chemical). In determining fertilizer doses the following should be considered: the reserve of soil nutrients (NPK), plant seed, organic fertilizers administered to the current or previous crop, anticipated production, water supply, etc. Among nutrients, grain production is most influenced by simultaneous administration of nitrogen and phosphorus.

Solid organic fertilizer spreaders should be judiciously designed to provide the necessary plant and soil nutrients. Special attention should be given to the uniformity of the application of fertilizers and the ratio of nutrients. The unevenness of nitrogen fertilizer application or application on weak soils provided with phosphorus and potassium can lead to nutritional imbalances, manifested through twinning, poor plant growth and burns on young leaves.

Given the effectiveness and economic efficiency of agricultural crop fertilization, everything possible must be done so that these crops are fertilized in a systematic way to achieve good results, represented by high level and quality outputs.

Special machines are used for mechanized application of solid organic fertilizers (livestock manure) obtained from fermentation platforms or as a solid fraction separated from slurry. Manure spreaders are generally semi-mounted trailers made of the following components: frame, hopper with floor conveyor, spreading devices (usually rotating mechanisms) and power transmission parts. They can also be truck-mounted, with the same working principles. The main characteristics differentiating manure spreaders are the type of spreading devices used, the location of the spreading devices (side or rear delivery) and the type of floor conveyor. The basic functions of a fertilizer spreader are [1]:

- to transport fertilizer to the field;

- to spread fertilizer evenly in the field at the required rate. 
The main types of floor conveyor used on commercial manure spreaders are chain and slats or scraper conveyors and augers. Another system consists of a moving panel, usually comprising a hydraulic cylinder assembly which used to push the material towards the spreading mechanism.

The spreading mechanisms of manure spreaders are usually made of rotating devices having three main functions: (1) striking the product with impacts to cause it to crumble, (2) pulverizing the product, i.e. breaking it into smaller pieces to allow for a good throwing distance and an acceptable evenness of distribution and (3) projecting the product away from the spreader at an acceptable distance and with an acceptable evenness of distribution along the entire spreading width. The spreading uniformity in the direction of travel is also important [2-4].

The most commonly used method for stable manure spreading uses vertical beaters (e.g. Bergmann spreader, Northren spreader). A manure spreader with horizontal beaters is also manufactured (West Point Design spreader, Pik Rite's Hydra-Ram spreader, Pöttinger spreader) and recently there has been an increasing number of manure spreaders with wide-angle spreading devices (e.g., Kemper spreader, Bergmann spreader [4-6].

The effect of manure fertilizer characteristics, specifically particle size, shape, density and strength on spreading performance has been the subject of several research papers, and was considered in detail by Duhovnik et al. [5]. While defining the technical process, the authors found that the manure spreading width directly depends on the dispersal assembly (essentially an ejection assembly) of the manure spreader. If very homogeneous material flow is achieved (of stable manure, in this case), then the centrifugal dispersal process can be defined in great detail. However, in this case, material flow is highly non-homogeneous. Therefore, the uniformity or maximum possible homogeneity of pieces of manure in the material flow prior to entering the dispersal assembly is an important condition for defining the quality of spreading [4]. Three types of distribution profiles were obtained after testing 9 spreaders in 41 test configurations with manure and compost [4]: triangular profile, with a maximum dosing at the center and a steady decline over the entire projection's halfwidths; trapezoidal profile, with a central part where the dose is maximum and constant, then rapidly decreases for each half-width projection; "M" profile with a central part subdosed and an overdosed part outside of the projection area.

\section{Materials and methods}

Among the most important factors influencing the distribution process there are the quality of material (moisture, density, straw content) and the construction of the distribution apparatus (the number of rotors, the distance between rotor axes, rotor diameter, spiral pitch and the type and number of blades mounted on the rotor) [1-3; 7].

A semi-mounted machine, recommended for small farms and individual households, was designed and built for administration of organic fertilizers. The manure spreaders MG 5 (Fig. 1) with a capacity of 5 tonnes have 4 vertical beaters dynamically balanced to ensure minimal flex and vibration when running at maximum rotating speed. On the floor, there is a scraper conveyor (Fig. 2) made of two longitudinal chains linked by U shaped steel bars.

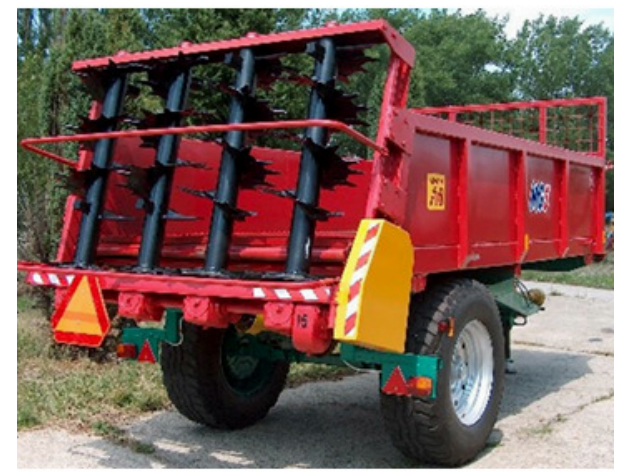

Fig. 1. Rear delivery vertical-axis beaters MG5

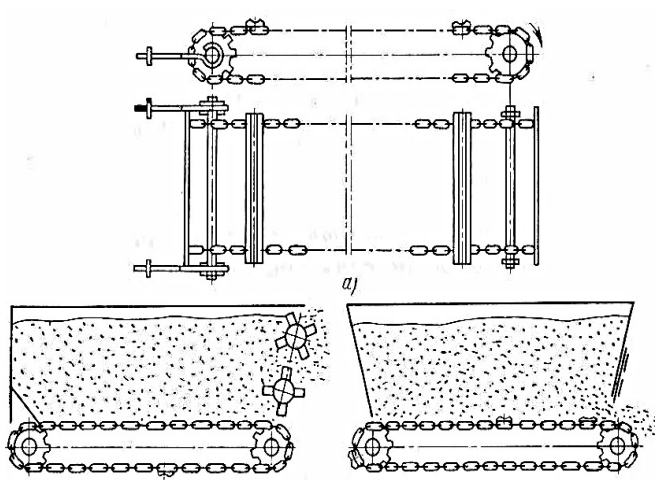

Fig. 2. Scraper conveyor [7] 
The theoretical application and discharge rate achievable with this spreader were calculated and are presented below. These can be obtained by varying the rotational speed of the rotors, varying the conveyor speed, or varying the working speed of the tractor-machine unit.

Depending on the characteristics of the fertilizer and the available quantities the machine can be loaded (up to the top level of the shutters) with masses between 1350 and $4050 \mathrm{~kg}$, corresponding to a ratio of the transport capacity of approximately 0.81 .

But in reality, the manure is loaded above the upper limit of the hopper having a parabolic shape at the top. This way, one can get maximum value by reaching the maximum allowable payload capacity of $5,000 \mathrm{~kg}$, where the coefficient of the transport capacity will be over 1.00 .

The formula for conveyor flow (Fig. 2) is

$$
q_{t}=B_{t} \cdot h \cdot v_{t} \cdot \gamma\left(\mathrm{kg} \cdot \mathrm{s}^{-1}\right),
$$

where $B_{t}-$ conveyor width, $\mathrm{m}$;

$h$ - the height of the manure layer in hopper m;

$v_{t}-$ conveyor speed, $\mathrm{m} \cdot \mathrm{s}^{-1}$;

$\gamma$ - manure density, $\mathrm{kg} \cdot \mathrm{m}^{-3}$

And introducing a correction coefficient $k$, the conveyor flow formula, (proposed by Russian scientist A.I. Mendelbaum [7]) is:

$$
q_{t}=B_{t} \cdot h \cdot v_{t} \cdot \gamma \cdot k\left(\mathrm{~kg} \cdot \mathrm{s}^{-1}\right) .
$$

The correction coefficient $k$ takes into consideration a number of factors which influence the actual flow rate of the conveyor. The most important of them is the difference between the material speed relative to the conveyor and the conveyor speed itself. This difference occurs because the conveyor slipping in relation to the material, and also because of the phenomena that occur within the displaced material determined by different layers' particles interaction, and material wastage. For scraper chain conveyors, an accurate analytical dependence between the material and the speed of the conveyor is missing from literature, so the difference is considered in the coefficient $k$ [7].

In addition, the correction coefficient $k$ takes into account the possible compression of the material, and therefore a change in density $\gamma$ which leads to a change of the of the cross-section $S$ of the material layer, and also from the influence of the geometric dimensions of the conveyor and the height of the layer of transported material.

The correction coefficient $k$ [7] may be presented as:

$$
k=k_{1} \cdot k_{2} \cdot k_{3} \cdot k_{4},
$$

where $k_{1}$ - coefficient of flow rate, which considers the difference between the average velocity of the material and the velocity of the conveyor;

$k_{2}$ - compression coefficient, which reflects the actual volume ratio of the weight of the material exiting the vehicle and volume weight after material scattering (shredded);

$k_{3}$ - coefficient of filling the transversal section $S$ with material;

$k_{4}$ - geometric flow coefficient, which characterizes the influence of the working volume on the conveyor flow.

In the general case, such a presentation of the $k$ coefficient is good for calculating any feeding working body. But in individual cases, some components of the coefficient $k$ can be ignored.

For manure scraper conveyor, $k_{3}$ and $k_{4}$ coefficients can be ignored, or can be considered equal to 1 [7].

From experimental data, the $k_{1}$ coefficient, can be accepted between 0.85 and $0.9, k_{2}$ varies from the beginning to the end of unloading the machine - initially it is equal to 1 , then increases and reaches 1.2 to 1.3 , and at the end of discharge again approaches 1 [7].

If we note that $B \times h=S\left(\mathrm{~m}^{2}\right)$, where $S$ is the cross-sectional area of the layer of material transported, the conveyor flow equation is:

$$
q_{t}=S \cdot v_{t} \cdot \gamma \cdot k\left(\mathrm{~kg} \cdot \mathrm{s}^{-1}\right) .
$$


Moreover, the flow rate is determined from the condition to ensure a standard quantity of fertilizer per unit area, $N$ (usually given in $\mathrm{kg} \cdot \mathrm{ha}^{-1}$ ) :

$$
q_{t}=B_{m} \cdot v_{m} \cdot \frac{N_{\min }\left(N_{\max }\right)}{10^{4}}\left(\mathrm{~kg} \cdot \mathrm{s}^{-1}\right),
$$

where $B_{m}-$ spreading width of the machine, $\mathrm{m}$;

$\mathrm{v}_{m}$ - machine speed, $\mathrm{m} \cdot \mathrm{s}^{-1}$;

$N_{\min }\left(N_{\max }\right)$ - application rate of fertilizer that lies between minimum and maximum, $\mathrm{kg} \cdot \mathrm{ha}^{-1}$.

Equalling equation 4 with equation 5, results in the relation used to calculate the speed of the conveyor scraper obtained from the condition of providing the necessary application rate [8]:

$$
S \cdot v_{t} \cdot \gamma \cdot k=B_{m} \cdot v_{m} \cdot N_{\text {min }}\left(N_{\max }\right) \cdot 10^{-4} \text {. }
$$

The result is the speed with which the conveyor must forward the fertilizer, $v_{t:}$ [3]

$$
v_{t \min }=\frac{N_{\min } \cdot B_{m} \cdot v_{m}}{S \cdot \gamma \cdot k \cdot 10^{4}} \text { and } v_{t \max }=\frac{N_{\max } \cdot B_{m} \cdot v_{m}}{S \cdot \gamma \cdot k \cdot 10^{4}}\left(\mathrm{~m} \cdot \mathrm{s}^{-1}\right) \text {. }
$$

Flow rate $q_{t}$ can be controlled by modifying conveyor speed $v_{t}$. Considering that the machine must ensure quantities between $N_{\min }$ and $N_{\max }$ the required adjustment domain of the conveyor speed is $v_{t}$. The range for $v_{t}$ for the constant $v_{m}$ is between $v_{t \min }$ and $v_{t \max }$.

Also, including conveyor speed and machine speed, in equation 7 , the distribution norm $\mathrm{N}$ can be presented as:

$$
N_{\max }=\frac{B_{\mathrm{t}} \cdot h \cdot v_{t_{\max }} \cdot \gamma \cdot k \cdot 10^{4}}{B_{m} v_{m}} \text { and } N_{\min }=\frac{B_{\mathrm{t}} \cdot h \cdot v_{t_{\min }} \cdot \gamma \cdot k \cdot 10^{4}}{B_{m} v_{m}}
$$

The equation (8) highlights the requirement that the operator maintains a constant travel speed $v_{m}$ of the unit to control the application rate $N$ per unit surface area.

\section{Results and discussion}

Since conveyor speed is low, $0.003-0.090 \mathrm{~m} \cdot \mathrm{s}^{-1}$ (frequently $0.0015-0.0500 \mathrm{~m} \cdot \mathrm{s}^{-1}$ ), the motor shaft is driven by the ratchet mechanism or by the scroller shaft gear, providing the opportunity to control the rotational speed.

Based on the given formulas we can calculate the achievable discharge rate and application rate depending on the design parameters, characteristics of manure, and material layer height or flow control gate opening. The results are obtained for a vertical manure spreader with width $B=2 \mathrm{~m}$, correction coefficient $k=0.85$, material height $H$ between $0.5 \mathrm{~m}$ and $1.1 \mathrm{~m}$.

There are considered 4 usual speeds for the scraper conveyor and for each type of material having a density $\gamma$ of $1207 \mathrm{~kg} \cdot \mathrm{m}^{-3}, 850 \mathrm{~kg} \cdot \mathrm{m}^{-3}, 540 \mathrm{~kg} \cdot \mathrm{m}^{-3}$ and $450 \mathrm{~kg} \cdot \mathrm{m}^{-3}$. The flow rate that can be achieved with a vertical rotors machine was calculated. Considering that the machine uses the hopper end-gate

\begin{tabular}{|c|c|c|c|c|c|c|}
\hline $\begin{array}{l}\text { Conveyor } \\
\text { speed, } \\
\mathbf{m} \cdot \mathbf{s}^{-1}\end{array}$ & \begin{tabular}{|} 
Bulk density \\
$\mathbf{k g} \cdot \mathbf{m}^{-3}$
\end{tabular} & $\begin{array}{l}\text { Mass flow } \\
\text { rate } Q, \\
\mathrm{~kg}^{-1} \mathrm{~s}^{-1} \text { for } \\
H=1.1 \mathrm{~m}\end{array}$ & $\begin{array}{c}\text { Bulk density, } \\
\qquad \mathrm{kg} \cdot \mathrm{m}^{-3}\end{array}$ & $\begin{array}{l}\text { Mass flow } \\
\text { rate } Q, \\
\mathrm{~kg} \cdot \mathrm{s}^{-1} \text { for } \\
H=0.8 \mathrm{~m}\end{array}$ & $\begin{array}{c}\text { Bulk density, } \\
\mathbf{k g} \cdot \mathbf{m}^{-3}\end{array}$ & $\begin{array}{l}\text { Mass flow } \\
\text { rate } Q, \\
\mathrm{~kg}^{-1} \mathrm{~s}^{-1} \text { for } \\
H=0.5 \mathrm{~m}\end{array}$ \\
\hline$V_{1}=0.0178$ & \multirow{4}{*}{$\begin{array}{c}\text { Livestock } \\
\text { manure } \\
\gamma=1207 \mathrm{~kg} \cdot \mathrm{m}^{-3}\end{array}$} & 40.17 & \multirow{4}{*}{$\begin{array}{c}\begin{array}{c}\text { Livestock } \\
\text { manure }\end{array} \\
\gamma=1207 \mathrm{~kg} \cdot \mathrm{m}^{-3}\end{array}$} & 29.22 & \multirow{4}{*}{$\begin{array}{c}\text { Livestock } \\
\text { manure } \\
\gamma=1207 \mathrm{~kg} \cdot \mathrm{m}^{-3}\end{array}$} & 18.26 \\
\hline$V_{2}=0.0298$ & & 67.26 & & 48.92 & & 30.57 \\
\hline$V_{3}=0.0466$ & & 105.18 & & 76.49 & & 47.81 \\
\hline$V_{4}=0.0651$ & & 146.94 & & 106.86 & & 66.79 \\
\hline
\end{tabular}
opened $0.5 \mathrm{~m}$ to $1.1 \mathrm{~m}$ maximum opening, the determined mass flow rates are presented in Table 1 .

Table 1

Mass flow rate achievable with rare delivery vertical -axis beaters MG5 
Table 1 (continued)

\begin{tabular}{|c|c|c|c|c|c|c|}
\hline $\begin{array}{c}\text { Conveyor } \\
\text { speed, } \\
\mathbf{m} \cdot \mathbf{s}^{-1}\end{array}$ & $\begin{array}{c}\text { Bulk density, } \\
\mathbf{k g} \cdot \mathrm{m}^{-3}\end{array}$ & $\begin{array}{l}\text { Mass flow } \\
\text { rate } Q, \\
{\mathrm{~kg} \cdot \mathrm{s}^{-1} \text { for }}_{H=1.1 \mathrm{~m}}\end{array}$ & $\begin{array}{c}\text { Bulk density, } \\
\qquad \mathbf{k g} \cdot \mathbf{m}^{-3}\end{array}$ & $\begin{array}{l}\text { Mass flow } \\
\text { rate } Q, \\
\mathrm{~kg} \cdot \mathrm{s}^{-1} \text { for } \\
H=0.8 \mathrm{~m}\end{array}$ & $\begin{array}{c}\text { Bulk density } \\
\mathbf{k g} \cdot \mathrm{m}^{-3}\end{array}$ & $\begin{array}{l}\text { Mass flow } \\
\text { rate } Q, \\
{\mathrm{~kg} \cdot \mathrm{s}^{-1} \text { for }}_{H=0.5 \mathrm{~m}}\end{array}$ \\
\hline$V_{1}=0.0178$ & \multirow{4}{*}{$\begin{array}{c}\text { Livestock } \\
\text { manure } \\
\gamma=850 \mathrm{~kg} \cdot \mathrm{m}^{-3}\end{array}$} & 28.29 & \multirow{4}{*}{$\begin{array}{c}\text { Livestock } \\
\text { manure } \\
\gamma=850 \mathrm{~kg} \cdot \mathrm{m}^{-3}\end{array}$} & 20.58 & \multirow{4}{*}{$\begin{array}{c}\text { Livestock } \\
\text { manure } \\
\gamma=850 \mathrm{~kg} \cdot \mathrm{m}^{-3}\end{array}$} & 12.86 \\
\hline$V_{2}=0.0298$ & & 47.36 & & 34.45 & & 21.53 \\
\hline$V_{3}=0.0466$ & & 74.07 & & 53.87 & & 33.67 \\
\hline$V_{4}=0.0651$ & & 103.48 & & 75.26 & & 47.03 \\
\hline$V_{1}=0.0178$ & \multirow{4}{*}{$\begin{array}{c}\text { Livestock } \\
\text { manure } \\
\gamma=540 \mathrm{~kg} \cdot \mathrm{m}^{-3}\end{array}$} & 17.94 & \multirow{4}{*}{$\begin{array}{c}\text { Livestock } \\
\text { manure } \\
\gamma=540 \mathrm{~kg} \cdot \mathrm{m}^{-3}\end{array}$} & 13.07 & \multirow{4}{*}{$\begin{array}{c}\text { Livestock } \\
\text { manure } \\
\gamma=540 \mathrm{~kg} \cdot \mathrm{m}^{-3}\end{array}$} & 8.17 \\
\hline$V_{2}=0.0298$ & & 30.09 & & 21.89 & & 13.68 \\
\hline$V_{3}=0.0466$ & & 47.05 & & 34.22 & & 21.39 \\
\hline$V_{4}=0.0651$ & & 65.74 & & 47.81 & & 29.88 \\
\hline$V_{1}=0.0178$ & \multirow{4}{*}{$\begin{array}{c}\text { Compost } \\
\gamma=450 \mathrm{~kg} \cdot \mathrm{m}^{-3}\end{array}$} & 14.97 & \multirow{4}{*}{$\begin{array}{c}\text { Compost } \\
\gamma=450 \mathrm{~kg} \cdot \mathrm{m}^{-3}\end{array}$} & 10.89 & \multirow{4}{*}{$\begin{array}{c}\text { Compost } \\
\gamma=450 \mathrm{~kg} \cdot \mathrm{m}^{-3}\end{array}$} & 6.81 \\
\hline$V_{2}=0.0298$ & & 25.07 & & 18.24 & & 11.40 \\
\hline$V_{3}=0.0466$ & & 39.21 & & 28.52 & & 17.82 \\
\hline$V_{4}=0.0651$ & & 54.78 & & 39.84 & & 24.9 \\
\hline
\end{tabular}

It is observed that the mass flow rate increases as the scraper conveyor speed and the bulk density increase.

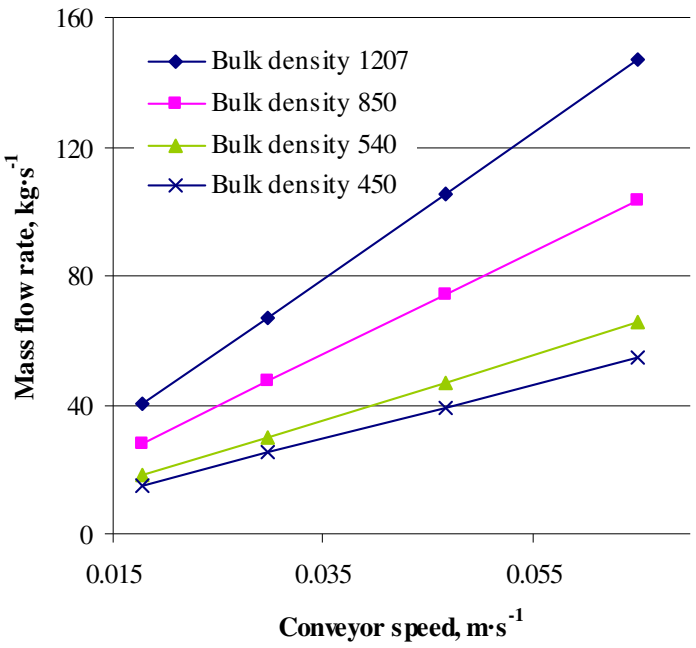

Fig. 3. Variation of mass flow rate with conveyor speed for $H_{\text {materia }}=\mathbf{1 . 1} \mathrm{m}$

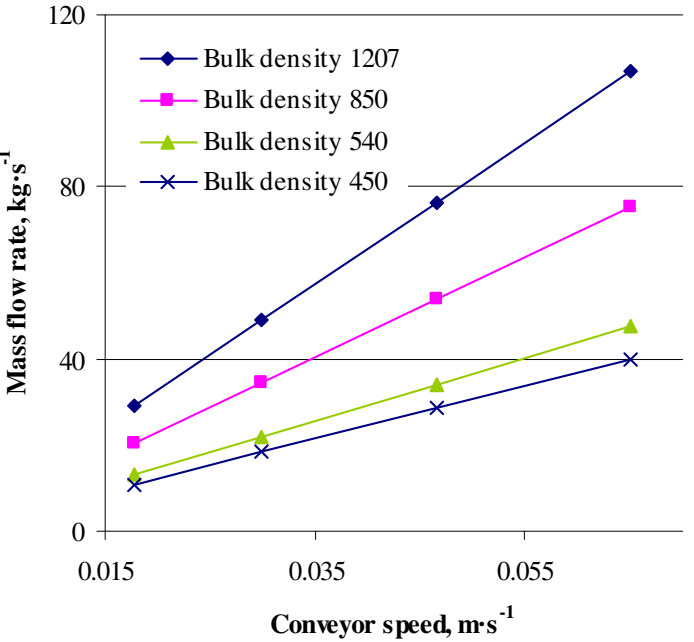

Fig. 4. Variation of mass flow rate with conveyor speed for $\boldsymbol{H}_{\text {material }}=\mathbf{0 . 8} \mathrm{m}$

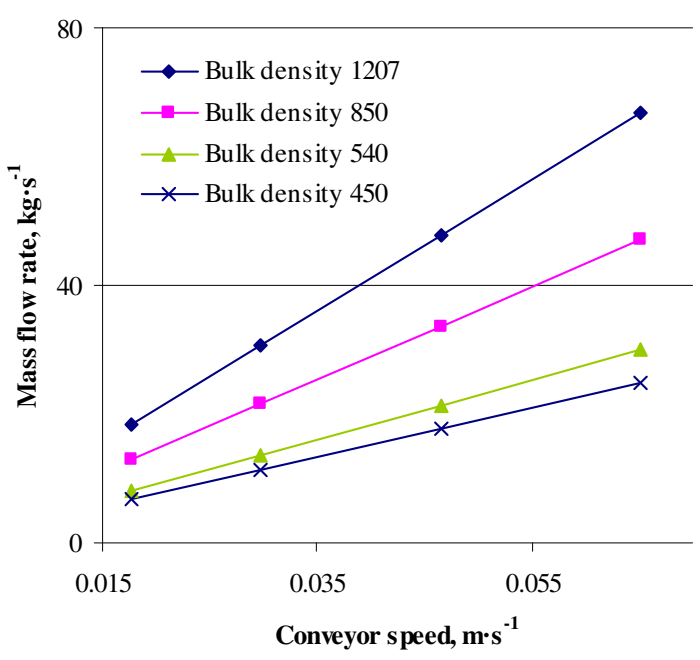

Fig. 5. Variation of mass flow rate with conveyor speed for $\boldsymbol{H}_{\text {material }}=\mathbf{0 . 5} \mathbf{m}$ 
We observe that the flow rate increases with the increase in the conveyor speed.

Table 2a

Theoretical application rate achievable with MG 5 manure spreader

\begin{tabular}{|c|c|c|c|c|c|c|c|c|}
\hline \multirow{3}{*}{$\begin{array}{l}\text { Travel } \\
\text { speed, } \\
\mathbf{k m} \cdot \mathbf{h}^{-1}\end{array}$} & \multicolumn{4}{|c|}{$N, \mathrm{~kg} \cdot \mathrm{m}^{-2}$} & \multicolumn{4}{|c|}{$N, \mathbf{k g} \cdot \mathrm{m}^{-2}$} \\
\hline & \multicolumn{4}{|c|}{$\gamma=1207 \mathrm{~kg} \cdot \mathbf{m}^{-3}$} & \multicolumn{4}{|c|}{$\gamma=850 \mathrm{~kg} \cdot \mathrm{m}^{-3}$} \\
\hline & $\begin{array}{c}V_{t r 1}= \\
0.06408 \\
\mathrm{~km} \cdot \mathrm{h}^{-1}\end{array}$ & $\begin{array}{c}V_{t r 2}= \\
0.10728 \\
\mathrm{~km} \cdot \mathrm{h}^{-1}\end{array}$ & $\begin{array}{c}V_{t r 3}= \\
0.16776 \\
\mathrm{~km} \cdot \mathrm{h}^{-1}\end{array}$ & $\begin{array}{c}V_{t r 4}= \\
0.23436 \\
\mathbf{k m}^{\prime} \cdot \mathbf{h}^{-1}\end{array}$ & $\begin{array}{c}V_{t r 1}= \\
0.06408 \\
\mathrm{~km}^{\prime} \cdot \mathrm{h}^{-1}\end{array}$ & $\begin{array}{c}V_{t r 2}= \\
0.10728 \\
\mathrm{~km} \cdot \mathrm{h}^{-1}\end{array}$ & $\begin{array}{c}V_{t r 3}= \\
0.16776 \\
\mathrm{~km} \cdot \mathrm{h}^{-1}\end{array}$ & $\begin{array}{c}V_{t r 4}= \\
0.23436 \\
\mathrm{~km} \cdot \mathrm{h}^{-1}\end{array}$ \\
\hline 2.58 & 5.606 & 9.385 & 14.676 & 20.503 & 3.948 & 6.609 & 10.335 & 14.439 \\
\hline 3.83 & 3.776 & 6.322 & 9.886 & 13.811 & 2.659 & 4.452 & 6.962 & 9.726 \\
\hline 4.16 & 3.477 & 5.821 & 9.102 & 12.716 & 2.448 & 4.099 & 6.410 & 8.955 \\
\hline 5.78 & 2.502 & 4.189 & 6.551 & 9.152 & 1.762 & 2.950 & 4.613 & 6.445 \\
\hline 6.17 & 2.344 & 3.924 & & 8.573 & 1.651 & 2.764 & 4.322 & 6.038 \\
\hline 7.68 & 1.883 & 3.153 & 4.930 & 6.888 & 1.326 & 2.220 & 3.472 & 4.850 \\
\hline 8.56 & 1.690 & 2.829 & 4.423 & 6.180 & 1.190 & 1.992 & 3.115 & 4.352 \\
\hline
\end{tabular}

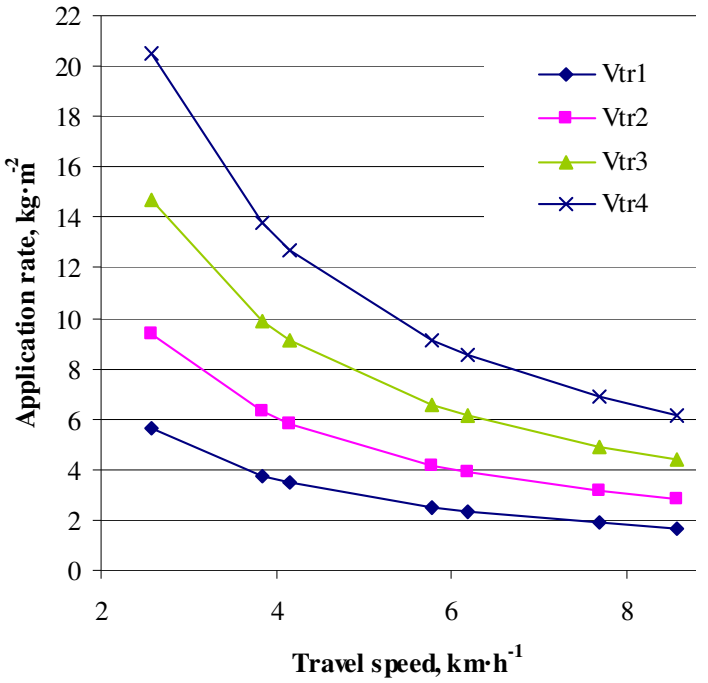

Fig. 6. Variation of application rate with travel for bulk density $\gamma=1207 \mathrm{~kg} \cdot \mathrm{m}^{-3}$

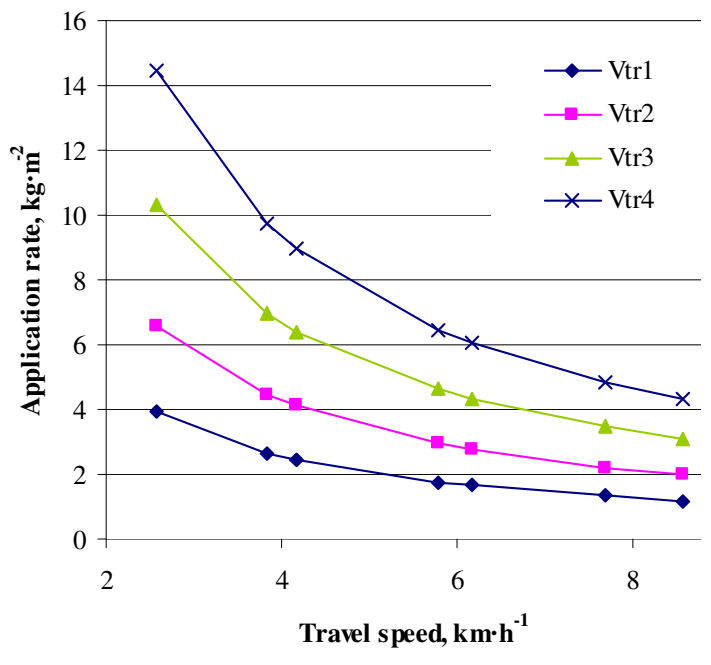

Fig. 7. Variation of application rate with travel for bulk density $\gamma=850 \mathrm{~kg} \cdot \mathrm{m}^{-3}$

It is important to know the application rates at different working speeds, needed to ensure the agrotechnical fertilizer requirements for crops. For the same fertilizers analysed before the application rates were calculated.

Table 2b - Theoretical application rate achievable with MG 5 manure spreader

\begin{tabular}{|c|c|c|c|c|c|c|c|c|}
\hline \multirow{3}{*}{$\begin{array}{l}\text { Travel } \\
\text { speed, } \\
\mathbf{k m} \cdot \mathbf{h}^{-1}\end{array}$} & \multicolumn{4}{|c|}{$N, \mathrm{~kg} \cdot \mathrm{m}^{-2}$} & \multicolumn{4}{|c|}{$N, \mathrm{~kg} \cdot \mathrm{m}^{-2}$} \\
\hline & \multicolumn{4}{|c|}{$\gamma=540 \mathrm{~kg} \cdot \mathrm{m}^{-3}$} & \multicolumn{4}{|c|}{$\gamma=450 \mathrm{~kg} \cdot \mathrm{m}^{-3}$} \\
\hline & $\begin{array}{c}V_{t r 1}= \\
0.06408 \\
\mathbf{k m} \cdot \mathbf{h}^{-1}\end{array}$ & $\begin{array}{c}V_{t r 2}= \\
0.10728 \\
\mathbf{k m} \cdot \mathbf{h}^{-1}\end{array}$ & $\begin{array}{c}V_{t r 3}= \\
0.16776 \\
\mathbf{k m} \cdot \mathbf{h}^{-1}\end{array}$ & $\begin{array}{c}V_{t r 4}= \\
0.23436 \\
\mathrm{~km} \cdot \mathrm{h}^{-1}\end{array}$ & $\begin{array}{c}V_{t r 1}= \\
0.06408 \\
\mathbf{k m} \cdot \mathbf{h}^{-1}\end{array}$ & $\begin{array}{c}V_{t r 2}= \\
0.10728, \\
\mathbf{k m} \cdot \mathbf{h}^{-1}\end{array}$ & $\begin{array}{c}V_{t r 3}= \\
0.16776 \\
\mathbf{k m} \cdot \mathbf{h}^{-1}\end{array}$ & $\begin{array}{c}V_{t r 4}= \\
0.23436 \\
\mathbf{k m} \cdot \mathbf{h}^{-1}\end{array}$ \\
\hline 2.58 & 2.508 & 4.199 & 6.566 & 9.173 & 2.090 & 3.499 & 5.472 & 7.644 \\
\hline 3.83 & 1.690 & 2.828 & 4.423 & 6.179 & 1.408 & 2.357 & 3.686 & 5.149 \\
\hline 4.16 & 1.555 & 2.604 & 4.072 & 5.689 & 1.296 & 2.170 & 3.394 & 4.741 \\
\hline \begin{tabular}{|l|}
5.78 \\
\end{tabular} & 1.120 & 1.874 & 2.931 & 4.094 & 0.933 & 1.562 & 2.442 & 3.412 \\
\hline 6.17 & 1.049 & 1.756 & 2.746 & 3.836 & 0.874 & 1.463 & 2.288 & 3.196 \\
\hline 7.68 & 0.843 & 1.411 & 2.206 & 3.081 & 0.702 & 1.175 & 1.838 & 2.568 \\
\hline 8.56 & 0.756 & 1.266 & 1.979 & 2.765 & 0.630 & 1.055 & 1.649 & 2.304 \\
\hline
\end{tabular}




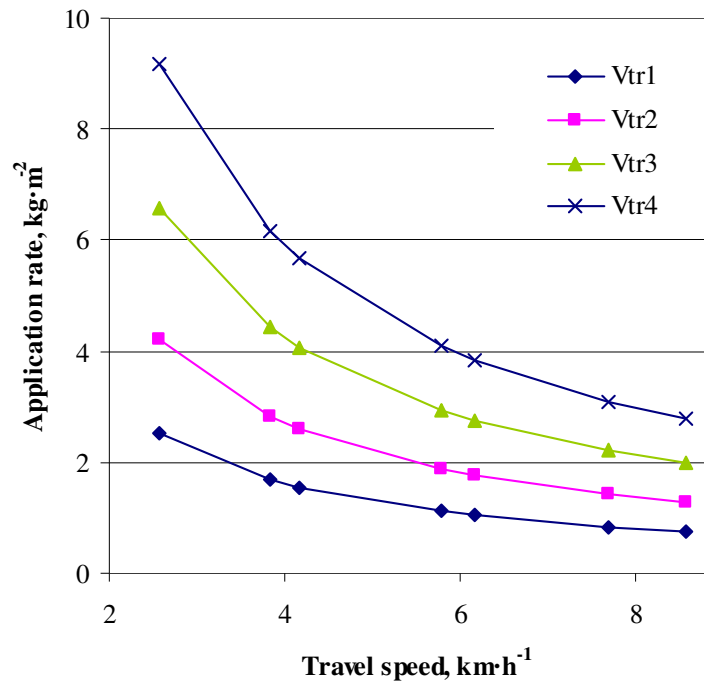

Fig. 8. Variation of application rate with travel for bulk density $\gamma=540 \mathrm{~kg} \cdot \mathrm{m}^{-3}$

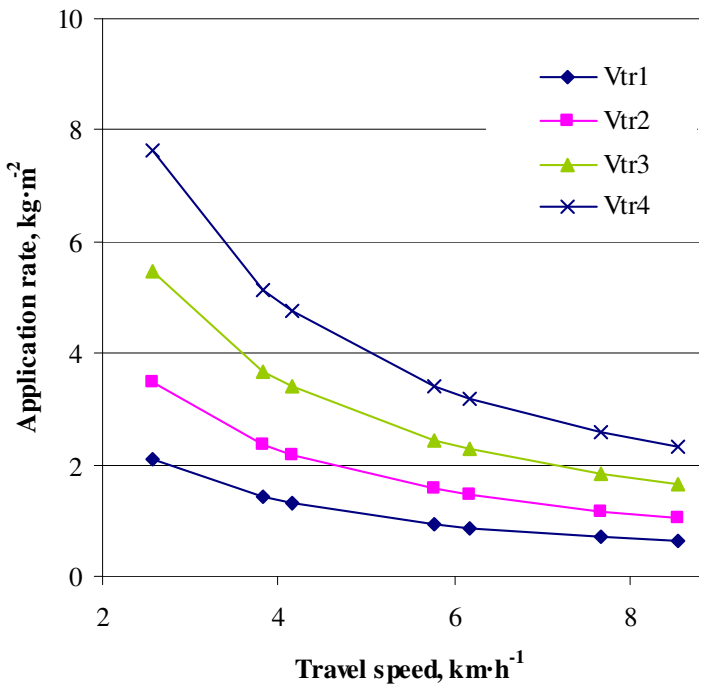

Fig. 9. Variation of application rate with travel for bulk density $\gamma=450 \mathrm{~kg} \cdot \mathrm{m}^{-3}$

In Tables $2 a$ and $2 b$ the application rates obtained per hectare are calculated for different travel speeds, conveyor speeds and for different bulk density. It can be observed that in order to obtain approximately the same norms the machine can be adjusted in several ways: for example, for the production of $2.5 \mathrm{~kg} \cdot \mathrm{m}^{-2}$ the machine can travel at $v_{m}=2.58 \mathrm{~km} \cdot \mathrm{h}^{-1}$ and $V_{t r}=0.06408 \mathrm{~km} \cdot \mathrm{h}^{-1}$ or it can travel at $v_{m}=4.16 \mathrm{~km} \cdot \mathrm{h}^{-1}$ and $V_{t r}=0.10728 \mathrm{~km} \cdot \mathrm{h}^{-1}$. However, usually the best economical solution (low fuel consumption) is chosen. Another option that can be chosen is the time of travel (rapidity of finishing the work of fertilization).

\section{Conclusions}

1. From the presented tables and charts it follows that the machine mass flow rate increases as conveyor speed increases. The mass flow rate also increases with the increase of the material bulk density.

2. At minimum load capacity $\left(H_{\text {material }}=0.5 \mathrm{~m}\right)$ the mass flow rate may vary between $6.81 \mathrm{~kg} \cdot \mathrm{s}^{-1}$ to $66.79 \mathrm{~kg} \cdot \mathrm{s}^{-1}$ and for maximum capacity $\left(H_{\text {material }}=1.1 \mathrm{~m}\right)$ the mass flow rate ranges between $14.97 \mathrm{~kg} \cdot \mathrm{s}^{-1}$ and $146.94 \mathrm{~kg} \cdot \mathrm{s}^{-1}$.

3. The application rates that can be obtained with the machine MG5 are between $0.629 \mathrm{~kg} \cdot \mathrm{m}^{-2}$ and $20.502 \mathrm{~kg} \cdot \mathrm{m}^{-2}$. They vary depending on the unit operating speed and the bulk density of the material. As the unit's operating speed increases the application rate decreases.

4. The MG5 machine complies with the distribution rules imposed by agrotechnical requirements and codes of good agricultural practices.

5. Knowing the manure application rates achievable with this type of machines, it will avoid over and under application of nutrients that will have negative environmental impact or will decrease yield potential.

6. For doing a correct land fertilizations it is a must to know the fertility level of the soil, the crop nutrients requirements, the amount of nutrients that the manure consist and the quantity of manure that the machine can spread.

\section{Acknowledgement}

This work was funded by the Ministry of Research and Innovation, "NUCLEU" Program, the Research National Program of Romania (PN 16240102 "Technology and innovative technical equipment for organic fertilizer, in orchards, with distribution in strips directly to the rows of trees"). 


\section{References}

1. Dermot F., "Fertilizer spreading - getting the mechanics right" Proceedings of Spring Scientific Meeting 2011, "Maximising fertiliser efficiency under changing legislation" February 8th, 2011 Horse and Jockey, Thurles, Co Tipperary.

2. Landry H. "Numerical modelling of machine-product interactions in solid and semi-solid manure handling and land applicatin" Doctoral thesis, University of Saskatchewan (Canada), 2004.

3. Landry, H., Lague, C., Roberge, M., Alam, M.T., "Physical and flow properties of solid and semisolid manure as related to the design of handling and land application equipment" CSAE/SCGR Paper 02214, AIC 2002 Meeting CSAE/SCGR Program Saskatoon, Saskatchewan July 14-17, 2002

4. Rousselet M., Mozoyer J., Évaluation des performances des épandeurs de fumier: premiers results selon la norme NF EN 13080, Ingénieries no.46, 2006, pp.79-92.

5. Duhovnik J ,Benedičič J , Bernik R., "Analysis and Design Parameters for Inclined Rotors Used for Manure Dispersal on Broadcast Spreaders for Solid Manures" Transactions of the ASAE, vol. 47(5), pp 1389-1404, 2004.

6. Ştefan (Popa) V., Ciupercă R.,. Popa L., Nedelcu A., Lazăr G., Petcu A.S.,. Zaica A., "The influence of physical characteristics of solid oganic fertilizers on quality of land spreading" INMATEH-Agricultural Engineering, vol.46-2, 2015, pp. 77-84.

7. Doganovsky M.G, Kozlowski E.B., "Machines for fertilizer application" Moscova, 1972.

8. Scripnic V., Babiciu P., “Agricultural machinery”, Bucharest, Ceres, 1979. 